\title{
Usage and Performance of Open Educational Resources among State Universities of Tamil Nadu Research Scholars
}

\author{
K.Sathish Kumar, Irwan Fathurrochman, M.Mahendraprabu, R.Ramnath, N.Sasi Kumar
}

\begin{abstract}
The new education system emphasizes the online based teaching-learning approaches. In particular, all the learners want to secure, open, affordable, and normal educational services. The open educational tools fulfill all the educational related problems to the learners. The study's key objective is to figure out the level of use of accessible educational services and find out the level of excellence in education among the state universities of Tamilnadu research scholars. A selection of 300 research scholars from 22 state universities in Tamilnadu state is chosen randomly for the study. The thesis was performed by using a survey approach from 17/10/2020 and 26/12/2020. Data is evaluated using percentage analysis and t-test. Findings show that 30 percent of the state universities research scholars have a high level of accessible educational opportunities and 24 percent of them have a high level of excellence in college. Results also suggest a substantial gap in the use of accessible educational services by male and female state universities research scholars. There is no substantial gap in education performance among male and female state universities research scholars concerning gender. The COVID-19 outbreak and paralysis also criticized the schooling of migrant workers and their children. Open educational opportunities are a viable school infrastructure in the future, including in a virus epidemic, storm, hurricane, world war, etc.
\end{abstract}

Keywords: Open Educational Resources; Open Educational Practices; Research Scholars; Creative Common.

\section{INTRODUCTION}

$\mathrm{O}_{\text {pen Educational Resources were designed to promote }}$ learning and teaching for free [1], [2] and simple use [3]-[5] for all people with Creative Common license[6], [7]. OER is an open license material that anyone will use for learning [6], [8], [9]. Creative Common (CC) license is also a profitless

Manuscript received on May 09, 2021

Revised Manuscript received on June 09, 2021.

Manuscript published on June 30, 2021.

* Correspondence Author

K.Sathish Kumar*, Department of Education, Alagappa University, Karaikudi (Tamil Nadu), India. Email: edusathish@gamail.com

Irwan Fathurrochman, Department of Educational Management, Institut Agama Islam Negeri Curup, Indonesia. E-mail: irwan@iaincurup.ac.id

M.Mahendra Prabu, Department of Education, Alagappa University, Karaikudi (Tamil Nadu), India. Email: eduprabu2011@gamail.com

R.Ramnath, Department of Education, Alagappa University, Karaikudi (Tamil Nadu), India.

N.Sasi Kumar, Department of Education, Alagappa University, Karaikudi (Tamil Nadu), India.

(C) The Authors. Published by Blue Eyes Intelligence Engineering and Sciences Publication (BEIESP). This is an open access article under the CC BY-NC-ND license (http://creativecommons.org/licenses/by-nc-nd/4.0/) association scheme that can grant open licenses [9]-[11]. It is allowed to the learners in the 5R operations [12] (see Fig. 1):

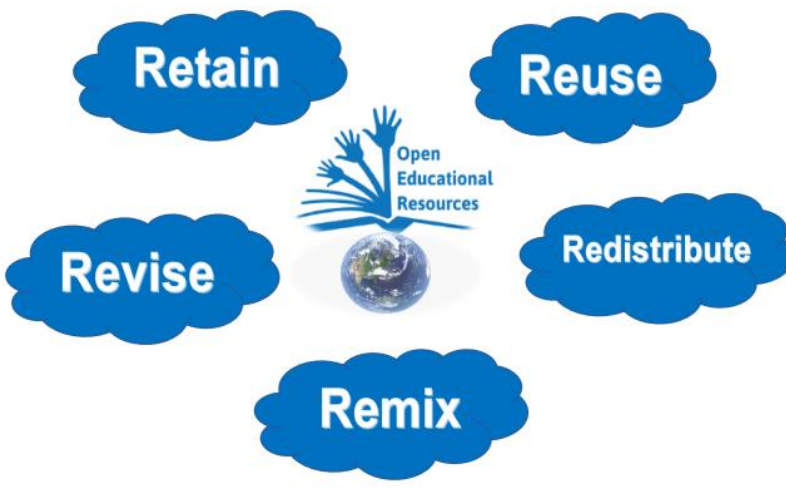

Fig. 1. 5R's of Open Educational Resources

Retain is called as Prepare and save copies of the material, Reuse is called as Again, and again use the content wherever, anytime, anyplace, Redistribute is called as Change the content and can noticeable in all languages, Remix is called as Link the content in all tools and Revise called as Exchange the combined content with other users[9], [12], [13].

Open Educational Resources (OER) are learning environment and study material on any format, electronic or otherwise, that are in the mainstream media or have been released under an open license that allows open access, reuse, replication, and redistribution by others with no or specific restrictions used only to support education[14], [15] and to where you can openly access, reuse, modify, and share[16],[17]. These recommendations sum up the main concerns and propose the integration of open education into higher education [18][19]. The objective is to enable governments and institutes to invest in the method of producing, adapting and using open education services and to make them a part of higher education in order to increase curricula and standard of teaching and minimize costs [6][8],[20]. These Guidelines were developed[24],[25], following extensive stakeholders in all the regions of the world, in order to support governments, educational institutions, superiors, academic staff, student organisations and guarantee/ accreditation bodies and re-excellence in quality, given the potential of OERs to develop systems in higher education[6],[8], [21],[23] and the Commonwealth of Learning[6]. Open education services consist of education content, software, resources for application and external links [26]. Resources for education is free.

Published By:

Blue Eyes Intelligence Engineering

\& Sciences Publication (BEIESP)

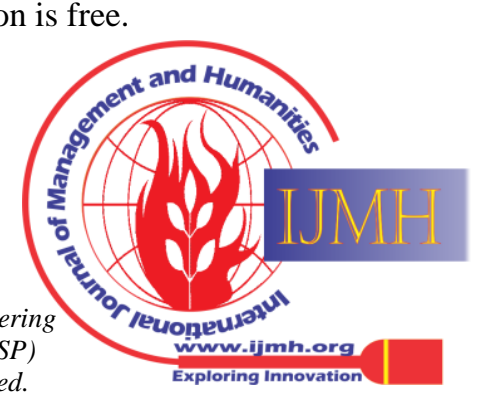


The OER in India is an open educational resource that includes classes and programs, curricula, didactic modules, student guidelines, textbooks, articles in research, videos, podcasts, assessment tools, interactive material (simulations), databases, software, applications and all other educational matters. [19],[27]-[31]. The UGC was classified as several universities fall under the Tamil Nadu State Universities in India. At present, there are 22 universities at the State University of Tamil Nadu in India. About 12,000 scholars in the present academic year in the state universities of Tamil Nadu[32],[33].

\section{SIGNIFICANCE OF THE STUDY}

The lifestyle of people is greatly influenced by open education opportunities. People are developing their lifestyle using books and materials such as radio, television, computers and the Internet [34]. It affects youth as well as old lives. The development of open educational infrastructure has developed a new cultural power, in which education roles compete with those of schools. In almost all areas of life, including education, family and leisure, it becomes essential. Accessible educational opportunities have a great influence on adolescents in contemporary society [35]. The children of today live in a world completely different from their parents. There is a large break from the current living standards of the previous decade. Open education has emerged as a prominent and important component of contemporary society. The creation of open educational infrastructure and curriculum is so interwoven that without comparison to the other, the debate is incomplete. Education incorporates those principles in the curriculum that no other subjects have. They are part of the training and preparation for life that the school expects its school students to play their part in the collective of intellectuals [36][37]. All of the subjects are taught because they offer liberal education.

\section{OBJECTIVES OF THE STUDY}

- Assess the extent of use by Tamilnadu State University researchers of open educational services.

- To determine the standard of educational achievement of Tamilnadu state universities.

- To identify, if any, the major gap in the use of open gender education

- Figure out why there is a considerable gap in gender educational success.

- Find out how important the use of open education tools and output is in the state universities of researchers of Tamilnadu.

\section{NULL HYPOTHESES}

H0:1 In the use of open education services there are no major differences between male and female Tamilnadu State Universities.

H0:2 There is no substantial gap in education results between the male and female universities in Tamilnadu.

H0:3 In the state universities of Tamilnadu research scholars there is no substantial relationship between open educational capital and success.

\section{REVIEW OF RELATED LITERATURE}

The researchers adopt the existing literature review model in table format and use the research papers for this literature analysis published in the period 2017 to 2021.

The researchers conclude that the existing study void is accessible teaching activities, according to this literature review. In particular, a minimum number of papers are available in open education activities for researchers only. Table 1 shows the corresponding literature summary. The researcher then chooses "the use and exercise of accessible educational tools among research researchers in education at State universities in Tamilnadu.',

Table I: Related Literature Review (2017-2021)

\begin{tabular}{|c|c|c|c|c|}
\hline \multirow{2}{*}{$\begin{array}{c}\text { Author } \\
\text { \& } \\
\text { Year }\end{array}$} & \multirow[b]{2}{*}{ Aim/Objective } & \multicolumn{2}{|c|}{ Methodology } & \multirow{2}{*}{$\begin{array}{c}\text { Result/ Findings } \\
\text { \& } \\
\text { Future Research }\end{array}$} \\
\hline & & $\begin{array}{l}\text { Sample Size/ } \\
\text { Respondent }\end{array}$ & Design/Tools & \\
\hline $\begin{array}{l}\text { Singh \& } \\
\text { Chauhan, } \\
\text { (2017) }\end{array}$ & $\begin{array}{l}\text { This study explores the } \\
\text { awareness of teacher } \\
\text { educators of conceptual } \\
\text { understanding, usability, } \\
\text { digital resources } \\
\text { requirements, open } \\
\text { education practise, and } \\
\text { policies on MOOCs. }\end{array}$ & $\begin{array}{l}\text { The sample size of this } \\
\text { study is } 156 \text { teachers. }\end{array}$ & $\begin{array}{l}\text { This analysis was conceived } \\
\text { at a level of understanding - } \\
\text { the descriptive analysis used } \\
\text { by this study. }\end{array}$ & $\begin{array}{l}\text { Studies indicate that teacher } \\
\text { educators have to pick an } \\
\text { appropriate knowledge of MOOCs } \\
\text { and provide teacher educators with } \\
\text { the facilities to learn and integrate } \\
\text { MOOCs into their daily practice } \\
\text { [38]. }\end{array}$ \\
\hline $\begin{array}{l}\text { Joshith, } \\
\text { (2020) }\end{array}$ & $\begin{array}{l}\text { This research article } \\
\text { explores understanding } \\
\text { of Open Educational } \\
\text { Resources and MOOC } \\
\text { system for Secondary } \\
\text { education Educators. }\end{array}$ & $\begin{array}{l}\text { The research has } \\
\text { undertaken } 300 \\
\text { secondary education } \\
\text { level teachers-the } \\
\text { experiment conducted } \\
\text { undertook } 30 \text { samples } \\
\text { for each control and } \\
\text { experimental groups. }\end{array}$ & $\begin{array}{l}\text { The research followed both } \\
\text { sample and experimental } \\
\text { approaches. Pre-test and } \\
\text { post-test were also } \\
\text { performed. Percentage } \\
\text { analysis, t-test, and impact } \\
\text { size analysis were planned. }\end{array}$ & $\begin{array}{l}\text { The study found that the population } \\
\text { of high school teachers still has no } \\
\text { knowledge of OERs and MOOCs. } \\
\text { This also has been shown to } \\
\text { encourage teacher professional } \\
\text { development through adequate } \\
\text { accessibility to accessible } \\
\text { educational resources [39]. }\end{array}$ \\
\hline
\end{tabular}

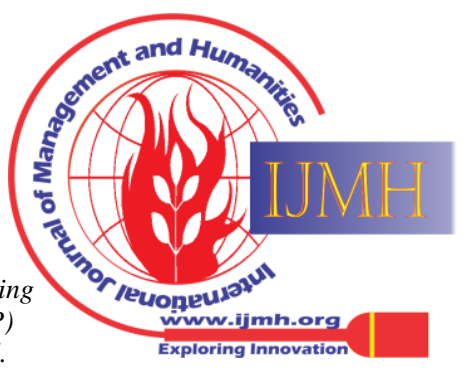




\begin{tabular}{|c|c|c|c|c|}
\hline $\begin{array}{l}\text { Nipa \& } \\
\text { Kermans } \\
\text { hachi, } \\
(2020)\end{array}$ & $\begin{array}{l}\text { The main goal is } \\
\text { clustering the use of } \\
\text { OER services for } \\
\text { professional and } \\
\text { non-professional pupils. }\end{array}$ & $\begin{array}{l}\text { A sample size of } 19 \\
\text { facets of Students \& } \\
\text { business. }\end{array}$ & $\begin{array}{l}\text { One classroom participated } \\
\text { with the computer based } \\
\text { virtual OER process, and } \\
\text { another class conducted the } \\
\text { classical textbook method. } \\
\text { A questionnaire was } \\
\text { conducted and given to } \\
\text { measure } 19 \text { innovations of } \\
\text { individuals. }\end{array}$ & $\begin{array}{l}\text { The research results would enable } \\
\text { educational institutions to use available } \\
\text { funding options to invest and install } \\
\text { OER material. } 78 \text { percent of learners } \\
\text { used personal devices such as } \\
\text { computers and electronic notebooks to } \\
\text { exchange content. The second-largest } \\
\text { device used to view the course } \\
\text { documentation has been described as } \\
\text { smartphones ( } 11 \text { percentage usage). } 19 \\
\text { percentage of learners selected a } \\
\text { personal desktop computer to prepare } \\
\text { for academic studies. Just a few } \\
\text { learners ( } 2 \text { percentage) used the printed } \\
\text { materials of the lesson plans [40]. }\end{array}$ \\
\hline $\begin{array}{l}\text { Santiago } \\
\& \quad \text { Ray, } \\
(2020)\end{array}$ & $\begin{array}{l}\text { The purpose of this } \\
\text { paper is to explain } \\
\text { services that promote } \\
\text { OER publication in } \\
\text { academic libraries. } \\
\text { Insights, prospects, and } \\
\text { problems are shared } \\
\text { surrounding the wider } \\
\text { open education } \\
\text { movement. }\end{array}$ & $\begin{array}{lr}\text { Case study } & \text { about } \\
\text { University } & \text { of } \\
\text { Houston } & \text { and } \\
\text { Washington. } & \\
\end{array}$ & $\begin{array}{l}\text { This paper includes two case } \\
\text { studies discussing the } \\
\text { advancement of OER } \\
\text { publishing systems at large, } \\
\text { public research universities } \\
\text {-Each initiative takes an } \\
\text { Author DIY approach to } \\
\text { publishing support and is in } \\
\text { the early years of promoting } \\
\text { OER acceptance and } \\
\text { creation. }\end{array}$ & $\begin{array}{l}\text { They highlight barriers and } \\
\text { opportunities for librarians promoting } \\
\text { OER projects, including integrating } \\
\text { current OER publication models, } \\
\text { managing institutional culture, pushing } \\
\text { OER services beyond availability, and } \\
\text { maintaining and scaling OER activities } \\
\text { with changing institutional support } \\
\text { [41]. }\end{array}$ \\
\hline $\begin{array}{l}\text { Luo et al., } \\
\text { (2020) }\end{array}$ & $\begin{array}{l}\text { The aim of this analysis } \\
\text { is to discuss techniques } \\
\text { for OER adoption that } \\
\text { encourage fast and } \\
\text { successful architecture. }\end{array}$ & $\begin{array}{l}\text { This study } \text { Taking } \\
\text { from } 51 \text { open } \\
\text { educational } \\
\text { materials analysis } \\
\text { made in nations all } \\
\text { over continents. }\end{array}$ & $\begin{array}{l}\text { This comprehensive } \\
\text { analysis of studies looks at } \\
\text { the evidential trends that are } \\
\text { prevalent in today's modern } \\
\text { world science. }\end{array}$ & $\begin{array}{l}\text { This research established that usability, } \\
\text { stability, and recreating are huge } \\
\text { obstacles that prevent OER from } \\
\text { undermining current textbook designs; } \\
\text { there are no substantial different forms } \\
\text { of learning performance when } \\
\text { educators adopt OER, and } \\
\text { implementation of OER with teaching } \\
\text { methods is problematic but can be } \\
\text { effective in fostering learning process } \\
\text { when properly implemented [42]. }\end{array}$ \\
\hline $\begin{array}{l}\text { X. Zhang } \\
\text { et al., } \\
(2020)\end{array}$ & $\begin{array}{l}\text { This thesis presents a } \\
\text { systematic analysis } \\
\text { based on published } \\
\text { publications related to } \\
\text { OER and OEP for } \\
\text { learning availability, } \\
\text { including students with } \\
\text { disabilities. }\end{array}$ & $\begin{array}{lr}\text { Conducted } & \text { a } \\
\text { systematic } & \text { review } \\
31 \text { articles. } & \\
\end{array}$ & $\begin{array}{l}\text { This thesis provides a } \\
\text { systematic analysis focusing } \\
\text { on existing } 31 \text { scientific } \\
\text { articles. } \\
\text { Based on the study of the } 31 \\
\text { established studies, } 1616 \\
\text { papers performed tests to } \\
\text { test the usability of OER. }\end{array}$ & $\begin{array}{l}\text { Nine nations have led studies about } \\
\text { OER and OEP for open instruction of } \\
\text { students with disabilities. Ecuador had } \\
11 \text { documents, Spain, with six papers, } \\
\text { UK-4, Greece-3, Ireland-2, Turkey, } \\
\text { Uruguay, Tunisia, Italy-1[43]. }\end{array}$ \\
\hline $\begin{array}{l}\text { Todorino } \\
\text { va \& } \\
\text { Wilkinso } \\
\text { n, (2020) }\end{array}$ & $\begin{array}{l}\text { The survey gathered } \\
\text { faculty's opinions about } \\
\text { the award program, } \\
\text { encounters with OER, } \\
\text { and participation in } \\
\text { open textbooks } \\
\text { publishing. }\end{array}$ & $\begin{array}{lr}\text { This } & \text { survey } \\
\text { analyzed } & \text { the } \\
\text { perspectives } & \text { of } \\
\text { faculty } & \text { who } \\
\text { received. } & \text { OAT } \\
\text { prizes in a textbook } \\
\text { accessibility } & \\
\text { competition } & \text { at } \\
\text { University } & \text { of } \\
\text { Rutgers. } & \\
\end{array}$ & $\begin{array}{l}\text { The survey questions } \\
\text { specifically asked about the } \\
\text { course materials used in } \\
\text { revised OAT courses, the } \\
\text { financial opportunity reward } \\
\text { presented, and the updated } \\
\text { course materials' effects on } \\
\text { students. It is demographic } \\
\text { issues. }\end{array}$ & $\begin{array}{l}\text { Responses say that the curriculum is } \\
\text { well received and that finances are } \\
\text { sufficient for implementing new course } \\
\text { materials. However, they also suggest } \\
\text { that even participating faculty differ } \\
\text { greatly in their experience and use of } \\
\text { OER and their participant in authoring } \\
\text { free textbooks [44]. }\end{array}$ \\
\hline $\begin{array}{l}\text { Schelling } \\
\text { er \& } \\
\text { Coghill, } \\
(2020)\end{array}$ & $\begin{array}{l}\text { This study would } \\
\text { discuss the use of OERs } \\
\text { to further lower the cost } \\
\text { of admission for } \\
\text { medical and nursing } \\
\text { education. }\end{array}$ & $\begin{array}{lr}\text { Review } & \text { based on } \\
\text { public } & \text { research } \\
\text { papers } & \end{array}$ & $\begin{array}{l}\text { Review based on public } \\
\text { research papers }\end{array}$ & $\begin{array}{l}\text { Librarians will be changing officers. } \\
\text { Administrative at the highest degree, } \\
\text { who may also foster reform, like } \\
\text { chancellors, presidents, proposal, vice } \\
\text { chancellors and deans. Librarians } \\
\text { should look beyond their buildings and } \\
\text { seek alliances and take OERs to their } \\
\text { respective institutions wherever they } \\
\text { can [45]. }\end{array}$ \\
\hline
\end{tabular}

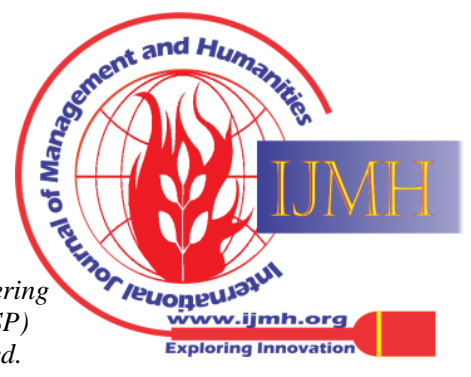




\begin{tabular}{|c|c|c|c|c|}
\hline $\begin{array}{l}\text { Lee, } \\
(2020)\end{array}$ & $\begin{array}{l}\text { Who opens distance } \\
\text { learning platforms, to } \\
\text { whom and for what? }\end{array}$ & $\begin{array}{l}\text { In August 2019, } 137 \\
\text { objects were } \\
\text { returned from the } \\
\text { above search. This } \\
\text { led to the selection } \\
\text { of } 29 \text { papers. }\end{array}$ & $\begin{array}{l}\text { The quest took the following } \\
\text { words: free, "university," } \\
\text { "higher education," "online } \\
\text { education," } \quad \text { "online } \\
\text { learning," } \\
\text { training," "distance } \\
\text { learning," "distance } \\
\text { learning," etc. It studied the } \\
\text { chosen documents by using } \\
\text { an in-depth theory approach. } \\
\text { It used the following words: } \\
\text { open learning. }\end{array}$ & $\begin{array}{l}\text { The findings indicate that while the } \\
\text { social mission of education for all } \\
\text { among various actors is becoming } \\
\text { increasingly important, there is a lack } \\
\text { of clarification on how the OEP really } \\
\text { works within the real-life context of } \\
\text { higher education and how it serves } \\
\text { disadvantaged students [46]. }\end{array}$ \\
\hline $\begin{array}{l}\text { Pitt et al., } \\
\text { (2020) }\end{array}$ & $\begin{array}{l}\text { Promoting open training } \\
\text { by open textbooks. It } \\
\text { focused on education } \\
\text { capital sensitivity. }\end{array}$ & $\begin{array}{lr}\text { United } & \text { Kingdom } \\
\text { Educators } & \text { Survey } \\
\text { Report. } & \text { In } \\
\text { September 2018, } \\
\text { more than } 4000 \text { UK } \\
\text { educators have been } \\
\text { invited to take part } \\
\text { via email. } \\
\end{array}$ & $\begin{array}{l}\text { The survey consisted of } 25 \\
\text { questions and was divided } \\
\text { into two parts. The first } \\
\text { section of the study dealt } \\
\text { with population issues. The } \\
\text { second half of the survey } \\
\text { focused on the use and } \\
\text { justification of textbooks. }\end{array}$ & $\begin{array}{l}\text { These results show techniques to } \\
\text { promote pedagogical creativity and } \\
\text { access by students to open textbooks on } \\
\text { a general basis [47]. }\end{array}$ \\
\hline $\begin{array}{l}\text { Wang et } \\
\text { al., } \\
(2021)\end{array}$ & $\begin{array}{l}\text { The study aims at } \\
\text { increasing the } \\
\text { awareness of factors } \\
\text { affecting the behaviour } \\
\text { of conservative school } \\
\text { teachers in the field of } \\
\text { digital technology. }\end{array}$ & $\begin{array}{l}709 \text { rural teachers in } \\
\text { sample size. } \\
\text { Teachers at } \\
\text { elementary and } \\
\text { secondary schools in } \\
\text { rural areas of } \\
\text { South-western } \\
\text { China attended the } \\
\text { meeting. }\end{array}$ & $\begin{array}{l}\text { An online survey sample } \\
\text { tool for collecting results. } \\
\text { Data research: IBM SPSS } \\
25 \text { and dispositional factors } \\
\text { exploratory factor analysis } \\
\text { (EFA), Mplus } 8.3 \\
\text { confirmatory factor testing } \\
\text { (CEFA). Then use the alpha } \\
\text { form of Cronbach. }\end{array}$ & $\begin{array}{l}\text { The study found that internally and } \\
\text { externally motivated behaviours and } \\
\text { behaviour shared within school and } \\
\text { outside school significantly affected } \\
\text { attitudes. Inner motivation was } \\
\text { however influenced positively, while } \\
\text { outside motivation influenced } \\
\text { negatively both attitude and sharing } \\
\text { behaviour. Future research is expected } \\
\text { to focus on the behaviour of teachers } \\
\text { on various online platforms for sharing } \\
{[16] \text {. }}\end{array}$ \\
\hline $\begin{array}{l}\text { Zou et al., } \\
\text { (2021) }\end{array}$ & $\begin{array}{l}\text { This research explores } \\
\text { the relationship between } \\
\text { public interactions and } \\
\text { participants' } \\
\text { respectability in the } \\
\text { learning process } \\
\text { network of a MOOC. }\end{array}$ & $\begin{array}{l}\text { A sample size of } 456 \\
\text { students enrolled in } \\
\text { Data Analysis for } \\
\text { Story - telling and } \\
\text { Exploration in News } \\
\text { reporting, an } \\
\text { instructional design } \\
\text { MOOC constructed } \\
\text { and controlled by a } \\
\text { massive research } \\
\text { institution in the } \\
\text { Southern United } \\
\text { States. }\end{array}$ & $\begin{array}{l}\text { This MOOC consists of four } \\
\text { modules. There are learning } \\
\text { resources in each module, } \\
\text { such as readings, } \\
\text { instructional videos, } \\
\text { quizzes, and a discussion } \\
\text { forum. Learners were } \\
\text { encouraged to participate in } \\
\text { the forum by the end of each } \\
\text { module to discuss certain } \\
\text { questions regarding the } \\
\text { module's topic. }\end{array}$ & $\begin{array}{l}\text { The results teach MOOC students how } \\
\text { to approach themselves strategically in } \\
\text { forums in order to maximize the } \\
\text { opportunities for peer participation and } \\
\text { achieve positive learning outcomes. } \\
\text { Results of our findings must be tested } \\
\text { by more research using MOOC data } \\
\text { from other subjects to examine the } \\
\text { effect of social involvement [48]. }\end{array}$ \\
\hline
\end{tabular}

\section{METHODOLOGY}

The aim was a research scientist in the Tamil Nadu state universities. The research scholar at Tamil Nadu State Universities is chosen as the random sampling technique. As those universities belong to the State Universities of Tamil Nadu in India, the grant commission of universities was classified. 22 universities in India are currently classified under Tamil Nadu state universities. About 12,000 research scientists in the present academic year at the state universities of Tamil Nadu. Random sample techniques and 300 educational researchers have been randomly chosen from Tamil Nadu State University to carry out a paper survey between 17/10/2020 and 26/12/2020. At the same time, the survey was performed on the internet, so that the online version of this questionnaire was completed by any student involved. Thus, both printed hard copy and soft copy surveys were included in the final figure. The researcher and guide develop the method to use open educational tools and education scale results.

\section{ANALYSIS OF DATA}

Table 2. Level of usage of open educational resources of state universities of Tamilnadu research scholars

\begin{tabular}{|c|c|c|c|c|c|}
\hline \multicolumn{2}{|c|}{ Low } & \multicolumn{2}{c|}{ Moderate } & \multicolumn{2}{c|}{ High } \\
\hline $\mathrm{N}$ & $\%$ & $\mathrm{~N}$ & $\%$ & $\mathrm{~N}$ & $\%$ \\
\hline 115 & 38.3 & 95 & 31.7 & 90 & 30 \\
\hline
\end{tabular}

Table 2 shows that $30 \%$ of the students have high level of usage of open educational resources

Table 3. Level of performance in education of state universities of Tamilnadu research scholars

\begin{tabular}{|c|c|c|c|c|c|}
\hline \multicolumn{2}{|c|}{ Low } & \multicolumn{2}{c|}{ Moderate } & \multicolumn{2}{c|}{ High } \\
\hline $\mathrm{N}$ & $\%$ & $\mathrm{~N}$ & $\%$ & $\mathrm{~N}$ & $\%$ \\
\hline 122 & 40.7 & 106 & 35.3 & 72 & 24 \\
\hline
\end{tabular}

Published By:

Blue Eyes Intelligence Engineering

\& Sciences Publication (BEIESP) 
Table 3 shows that $24 \%$ of the students have high level performance in education

\section{Hypothesis $\left(\mathrm{H}_{0}\right): 1$}

In the use of open education services there are no major differences between male and female Tamilnadu State Universities.

Table 4. Significant difference between male and female state universities of Tamilnadu research scholars in their usage of open educational resources

In Table 4, calculated t-value 3,969 is higher than the 0.05 table value, and consequently there is a considerable difference in the use of open educational resources between male and female research students.

\section{Hypothesis $\left(\mathrm{H}_{0}\right): 2$}

There is no substantial gap in education results between the male and female universities in Tamilnadu.

Table 5. Significant difference between male and female state universities of Tamilnadu research scholars in their performance in education

\begin{tabular}{|c|c|c|c|c|}
\hline Gender & $\mathbf{N}$ & Mean & SD & t-value \\
\hline Male & 127 & 57.50 & 14.56 & 2.55 \\
\hline Female & 173 & 52.70 & 17.10 & \\
\hline
\end{tabular}

Table 5. The calculated t-value 2.55 shows a significant difference in educational performance between Tamilnadu state universities and between women and men, above the table value of 0.05 .

\section{Hypothesis $\left(\mathrm{H}_{\mathbf{0}}\right)$ : 3}

In the state universities of Tamilnadu research scholars there is no substantial relationship between open educational capital and success.

Table 6. Significant relationship between usage of open educational resources and performance in education among state universities of Tamilnadu research scholars

\begin{tabular}{|c|c|}
\hline Variables & $\begin{array}{c}\text { Calculated r- } \\
\text { Value }\end{array}$ \\
\hline $\begin{array}{c}\text { Usage of open } \\
\text { educational resources }\end{array}$ & 0.038 \\
\hline $\begin{array}{c}\text { Performance in } \\
\text { education }\end{array}$ \\
\hline
\end{tabular}

In Table 6 above. Since the value of measured ' $r$ ' is less than the value of the table it is unrelated to the use of open education and success in training of Tamilnadu state universities.

\section{FINDINGS AND IMPLEMENTING AREAS OF OPEN EDUCATIONAL RESOURCES (OER)}

There is a major gap in Tamilnadu's open educational resources between male and female state universities. There is a considerable gap in educational success between men and women academic scholars. There is no important link between open educational infrastructure and educational success among the Tamilnadu state universities.

\begin{tabular}{|c|c|c|c|c|}
\hline Gender & $\mathbf{N}$ & Mean & SD & t-value \\
\hline Male & 127 & 68.19 & 9.56 & \multirow{2}{*}{3.96} \\
Female & 173 & 62.90 & 12.60 & \\
\hline
\end{tabular}

As practices in the area of science to help researchers OEP is widely used. It is very useful for reuse, use of copyright, etc. in the field of science. In India, OER and OEP are not so much brought into the field of education but will extend to our country for the next 10 years. We had recently kept MOOC, NPTEL classes as a product or usage for OER [49]-[52]. OER will become a free education tool like it is in India in the future. As regards free human and educational capital, OER and OEP have an indirect impact on GBP. In pandemic circumstances [53]-[55], OER is useful between students (such as the COVID-19 lock-down), since students are currently able to learn from their distant position without arriving at the school. OEP is also useful in this pandemic condition to the researchers, the academics and the professors. In the human resources market, OER and OEP are introduced to improve a nation's education target [56]-[59]. OER offers the educational sector free software and readers such as open source learning tools. And in the field of education it is used more widely. COVID-19 is the most influential virus in the country. More than $91 \%$ of students around the country lost their fundamental right to education when many educational establishments were shut down [53]-[55],[60]-[63].

During this time there are also lessons learnt from human civilization. We know the importance of distance learning and open tools to have the fundamental resources. We are also obliged to bring about the greatest transformation in the future school sector. It is in great fear that people could kill the older children and the sick because of this coronal virus [49],[64],[65]. In fact, parents find it difficult to send their children to school. All educational institutions therefore need technology improvements, open educational resources and facilities. Even if the spread of the disease is uncommon, students are still given open educational opportunities in their learning process. And the "OER" is the standard solution for all disasters that have an impact on students' education (virate outbreak, war, flooding, rain, recession, famines, storms, etc.). Education should be free and OER supports and promotes this thinking mainly.

\section{CONCLUSION}

The OER has evolved exponentially over the last couple of years to fulfil its needs. This is an absolute necessity in the 21st century. OER helps to digitise schooling using the latest technologies in order to increase education quality. At present, OER is commonly used in institutes for modernising the age of pen-notebooks into the era of digital learning in order to make cum tools available to everyone every day, wherever. Education should be unrestricted, and the OER respects and encourages this thinking primarily. OER helps in any case to adopt for research.

The COVID-19 outbreak and paralysis challenged migrants' and their children's schooling. Open educational services and OEP are a sustainable and simple method of education for the future even though the flu is epidemic, storm, flooding and the global war. The OEP is a system for education and education in a holistic manner. The transparent and free education services provide students with confidence and freedom to learn.

Blue Eyes Intelligence Engineering

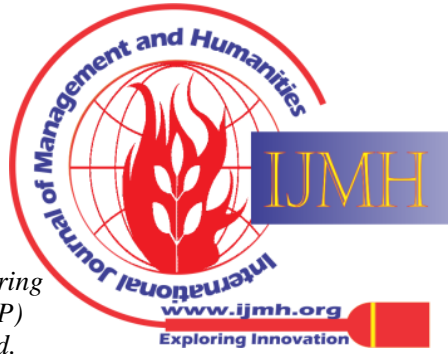


Researchers should be motivated to carry out small experiments in everyday life on the influence of open educational services. Science supervisors should promote and guide the use of open training tools to improve the educational success of research scholars.

\section{ACKNOWLEDGMENT}

They would like to thank the research scholars from the State Universities of Tamil Nadu, India.

\section{Competing interests}

No conflict of interest may be declared by the author.

\section{Contributions}

Each author has made a uniform contribution to this article. The final manuscript has been read and authorized by both contributors.

\section{Availability of Data and Materials}

The data sets generated and evaluated during the present analysis are not accessible publicly for reasons of privacy, but are available on fair request by the corresponding author.

\section{REFERENCES}

1. R. Halstead-Nussloch and R. Rutherfoord, "Tips for sources of cost-free and open educational resources to reduce textbook costs in IT courses," in SIGITE 2019 - Proceedings of the 20th Annual Conference on Information Technology Education, Sep. 2019, p. 174 doi: 10.1145/3349266.3351359.

2. R. A. Martin, "Finding free and open access resources: A value-added service for patrons," J. Interlibrary Loan, Doc. Deliv. Electron. Reserv., vol. 20, no. 3, pp. 189-200, Jul. 2010, doi: 10.1080/1072303X.2010.491022.

3. M. S. V. Kumar, "From open resources to educational opportunity," ALT-J, vol. 13, no. 3, pp. 241-247, Oct. 2005, doi: 10.1080/09687760500376512.

4. A. M. Korhonen, S. Ruhalahti, and M. Veermans, "The online learning process and scaffolding in student teachers' personal learning environments," Educ. Inf. Technol., vol. 24, no. 1, pp. 755-779, Jan. 2019, doi: 10.1007/s10639-018-9793-4.

5. E. A. Horn, R. Anderson, and K. Pierick, "Open educational resources (OERs) in self-directed competency-based education," Inf. Discov. Deliv., vol. 46, no. 4, pp. 197-203, Nov. 2018, doi: 10.1108/IDD-02-2018-0005.

6. Kumar, K. S., Prabu, M. M., Kalaiyarasan, G., Ramnath, R., Kumar, N. S., Mookkiah, M., Kumar, M. A., \& M.Manida, "Impact of the Open Educational Practices through Academic Achievement with Emotional, Social and Academic Adjustment among Researchers,' International Journal of Research Publication and Reviews., 2(4), 434-444 (2021).

7. T. Anderson, A. Gaines, C. Leachman, and E. P. Williamson, "Faculty and Instructor Perceptions of Open Educational Resources in Engineering," Ref. Libr., vol. 58, no. 4, pp. 257-277, Oct. 2017, doi: 10.1080/02763877.2017.1355768.

8. M. L. Valentino, "Donor funded Open Educational Resources: making the case," Bottom Line, vol. 28, no. 4, pp. 112-118, Dec. 2015, doi: 10.1108/BL-07-2015-0016.

9. J. Van Allen and S. Katz, "Teaching with OER during pandemics and beyond," Journal for Multicultural Education. Emerald Group Publishing Ltd., 2020, doi: 10.1108/JME-04-2020-0027.

10. X. Ren, "The undefined figure: Instructional designers in the open educational resource (OER) movement in higher education," Educ. Inf. Technol., vol. 24, no. 6, pp. 3483-3500, Nov. 2019, doi: 10.1007/s10639-019-09940-0.

11. C. L. Ferguson, "Open Educational Resources and Institutional Repositories," Ser. Rev., vol. 43, no. 1, pp. 34-38, Jan. 2017, doi: 10.1080/00987913.2016.1274219.

12. Risdianto, E., Wachidi, W., Riyanto, R., Alexon, A., Fathurrochman, I., \& Kusen, K. (2021). Blended Learning Model Based on Massive Open Online Courses (MOOCs) Assisted by Augmented Reality (BMA) Model as the Electronic Learning Media in the Pandemic Covid-19. AL-ISHLAH: Jurnal Pendidikan, 13(1), 228-241.
13. D. A. Wiley, "Open educational resources: undertheorized research and untapped potential," Educ. Technol. Res. Dev., Nov. 2020, doi: 10.1007/s11423-020-09907-w.

14. J. Burchardt, "Researchers Outside APC-Financed Open Access," SAGE Open, vol. 4, no. 4, p. 215824401455171, Dec. 2014, doi: $10.1177 / 2158244014551714$.

15. L. I. G. Pérez, M. S. R. Montoya, and F. J. García-Peñalvo, “Open access to educational resources in energy and sustainability: Usability evaluation prototype for repositories," in ACM International Conference Proceeding Series, Nov. 2016, vol. 02-04-Nove, pp. 1103-1108, doi: 10.1145/3012430.3012654.

16. J. Wang, D. E. H. Tigelaar, and W. Admiraal, "Rural teachers' sharing of digital educational resources: From motivation to behavior," Comput. Educ., vol. 161, Feb. 2021, doi 10.1016/j.compedu.2020.104055.

17. C. Gang, "Design of Digital Educational Resource Platforms in University," in Proceedings - International Symposium on Computer Science and Computational Technology, ISCSCT 2008, 2008, vol. 1, pp. 142-145, doi: 10.1109/ISCSCT.2008.126.

18. Kumar, K., Mahendraprabu, M. Open educational practices of SWAYAM programme among research scholars. Educ Inf Technol (2021). https://doi.org/10.1007/s10639-021-10495-2

19. N. Hood and A. Littlejohn, "Knowledge typologies for professional learning: educators' (re)generation of knowledge when learning open educational practice," Educ. Technol. Res. Dev., vol. 65, no. 6, pp 1583-1604, Dec. 2017, doi: 10.1007/s11423-017-9536-z.

20. C. Herodotou, S. Heiser, and B. Rienties, "Implementing randomised control trials in open and distance learning: a feasibility study," Open Learn., vol. 32, no. 2, pp. 147-162, May 2017, doi: 10.1080/02680513.2017.1316188.

21. C. Blyth, "Open Educational Resources and the New Classroom Ecology," Mod. Lang. J., vol. 98, no. 2, pp. 662-664, Jun. 2014, doi 10.1111/j.1540-4781.2014.12096.x.

22. K.Sathish Kumar, M.Mahendraprabu, G.Kalaiyarasan, "Open Educational Practices among Research Scholars in Education," Ahalia International Journal of Advanced Science and Technology, vol. 1, no. 1, pp. 527-540, March. (2021).

23. Kumar, K. S., \& Mahendraprabu, M. (2020). Awareness of swayam programme among the Postgraduate students. LAP LAMBERT Academic Publishing. https://www.amazon.com/Awareness-swayam-programme-Postgrad uate-students/dp/6203193445.

24. Kumar, K. S., \& Mahendraprabu, M. (2021).OPEN EDUCATIONAL PRACTICES BASED ON MOOC. Notion Press. https://notionpress.com/read/open-educational-practices-based-on-m ooc.

25. Kumar, K. S. (2018). International conferences on curriculum and instructional designing for global education. In SOCIAL MEDIA AS A LEARNING TOOL IN MODERN EDUCATION TREND. https://www.researchgate.net/publication/327971761_SOCIAL_ME DIA AS A LEARNING_TOOL_IN_MODERN_EDUCATION_T REND.

26. Ü. Avc1 Yücel, "Perceptions of pedagogical formation students about Web 2.0 tools and educational practices," Educ. Inf. Technol., vol. 22 no. 4, pp. 1571-1585, Jul. 2017, doi: 10.1007/s10639-016-9508-7.

27. A. Murphy, "Open educational practices in higher education Institutional adoption and challenges," Distance Educ., vol. 34, no. 2 pp. 201-217, Aug. 2013, doi: 10.1080/01587919.2013.793641.

28. Kumar, M. A., Gopalsamy, D. S., Shanmuganathan, S., Ganesan, S., \& Kumar, K. S. (2021). INDIA'S FOREIGN TRADE PERFORMANCE OF AGRICULTURAL PRODUCTS IN MALDIVES. International Research Journal of Modernization in Engineering Technology and Science, 03(04), 1923-1930.

29. E. Ossiannilsson, Z. Altınay, and F. Altınay, "Towards fostering quality in open online education through OER and MOOC practices," Lect. Notes Educ. Technol., no. 9783662529232, pp. 189-204, 2016, doi: 10.1007/978-3-662-52925-6_10.

30. S. P. Karunanayaka and S. Naidu, "A design-based approach to support and nurture open educational practices," Asian Assoc. Open Univ. J., vol. 12, no. 1, pp. 1-20, May 2017, doi: 10.1108/aaouj-01-2017-0010.

31. F. Nascimbeni, D. Burgos, L. M. Campbell, and A. Tabacco, "Institutional mapping of open educational practices beyond use of Open Educational Resources," Distance Educ., vol. 39, no. 4, pp. 511-527, Oct. 2018, doi:

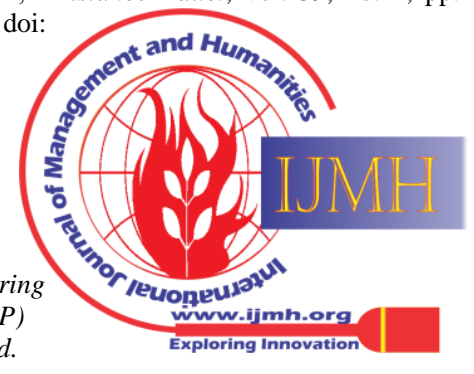


10.1080/01587919.2018.1520040.

32. Kumar, K. S., Mahendra Prabu, M., Kalaiyarasan, G., Ramnath, R., Sasi Kumar, N., Mookkiah, M., ... B, R. (2021). OPEN EDUCATIONAL PRACTICES FOR RESEARCH EFFECTIVENESS TO RESEARCH SCHOLAR. International Research Journal of Modernization in Engineering Technology and Science, 3(4), 113-121.

33. M.Mahendraprabu, K.Sathish Kumar, M.Mani, P.Saravana Kumar , "Open Educational Resources and their Educational Practices in Higher Education," Mukt Shabd Journal, vol. 10, no. 2, pp. 527-540, Feb.

2021 https://doi.org/10.0014.MSJ.2021.V10I2.0086781.118753.

34. B. Nkuyubwatsi, "Revisiting the reusability and openness of resources in the Massachusetts institute of technology Open Courseware," J. Interact. Media Educ., vol. 2018, no. 1, pp. 1-9, 2018, doi: 10.5334/jime.447.

35. W. Ian O'Byrne, V. Roberts, R. Labonte, and L. Graham, "Teaching, learning, and sharing openly online," J. Adolesc. Adult Lit., vol. 58 no. 4, pp. 277-280, Dec. 2014, doi: 10.1002/jaal.365.

36. Kumar, K.Sathish; Mahendraprabu, M.; Kalaiyarasan, G.; R.Ramnath, R.; Kumar, N.Sasi; and Mookkiah, Mani, "Social Media as an Open Educational Practice Tools and Challenges" (2021) Library Philosophy and Practice (e-journal). 5265 https://digitalcommons.unl.edu/libphilprac/5265.

37. Kumar, K. S., \& Mahendraprabu, M. (2021). PERCEPTION OF OER AND OEP. Notion Press. https://notionpress.com/read/perception-of-oer-and-oep.

38. G. Singh and R. Chauhan, "Awareness towards Massive Open Online Courses (MOOCs) and their usage for Teacher Education in India,' Asian J. Distance Educ., vol. 12, no. 2, pp. 81-88, 2017.

39. V. P. Joshith, "Technology Exploration in Teaching and Learning Perspectives on Open Educational Resources ( OER ) and Massive Open Online Course ( MOOC )," vol. XII, no. Iii, pp. 1238-1242, 2020.

40. T. J. Nipa and S. Kermanshachi, "Assessment of open educational resources (OER) developed in interactive learning environments," Educ. Inf. Technol., vol. 25, no. 4, pp. 2521-2547, Jul. 2020, doi: 10.1007/s10639-019-10081-7

41. A. Santiago and L. Ray, "Navigating support models for OER publishing: case studies from the University of Houston and the University of Washington," Ref. Serv. Rev., vol. 48, no. 3, pp. 397-413, Jul. 2020, doi: 10.1108/RSR-03-2020-0019.

42. T. Luo, K. Hostetler, C. Freeman, and J. Stefaniak, "The power of open: benefits, barriers, and strategies for integration of open educational resources," Open Learn., vol. 35, no. 2, pp. 140-158, May 2020, doi: 10.1080/02680513.2019.1677222.

43. X. Zhang et al., "Accessibility within open educational resources and practices for disabled learners: a systematic literature review," Smart Learning Environments, vol. 7, no. 1. Springer, Dec. 01, 2020, doi: 10.1186/s40561-019-0113-2.

44. L. Todorinova and Z. T. Wilkinson, "Incentivizing faculty for open educational resources (OER) adoption and open textbook authoring," J. Acad. Librariansh., vol. 46, no. 6, Nov. 2020, doi: 10.1016/j.acalib.2020.102220

45. J. Schellinger and J. G. Coghill, "Open Education Resources: Are We Ready for Prime Time?," J. Electron. Resour. Med. Libr., vol. 17, no. 1-2, pp. 49-55, Apr. 2020, doi: 10.1080/15424065.2020.1760163.

46. K. Lee, "Who opens online distance education, to whom, and for what?," Distance Educ., vol. 41, no. 2, pp. 186-200, Apr. 2020, doi: 10.1080/01587919.2020.1757404.

47. R. Pitt, K. Jordan, B. de los Arcos, R. Farrow, and M. Weller, "Supporting open educational practices through open textbooks," Distance Educ., vol. 41, no. 2, pp. 303-318, Apr. 2020, doi: 10.1080/01587919.2020.1757411.

48. W. Zou, X. Hu, Z. Pan, C. Li, Y. Cai, and M. Liu, "Exploring the relationship between social presence and learners' prestige in MOOC discussion forums using automated content analysis and social network analysis," Comput. Human Behav., vol. 115, Feb. 2021doi:10.1016/j.chb.2020.106582

49. Mani Mookkiah, Mahendraprabu, Kalaiyarasan, Ramnath, Sasikumar, Sathish Kumar, Sathyaraj , "YOGA BASED INTERVENTION STRATEGIES IN ACCELERATING SELF-EFFICACY AMONG PRIMARY SCHOOL TEACHERS,' Elementary Education Online, vol. 20, no. 4. pp. 794-805, 2021 , https://doi.org/10.17051/ilkonline.2021.04.85

50. Kumar, K.Sathish; Mahendraprabu, M.; Kalaiyarasan, G.; R.Ramnath, R.; Kumar, N.Sasi; and Mookkiah, Mani, "Social Media as an Open Educational Practice Tools and Challenges" (2021) Library Philosophy and Practice (e-journal). 5265. https://digitalcommons.unl.edu/libphilprac/5265.

51. M. Guerrero, S. Heaton, and D. Urbano, "Building universities" intrapreneurial capabilities in the digital era: The role and impacts of Massive Open Online Courses (MOOCs)," Technovation, 2020, doi: 10.1016/j.technovation.2020.102139.

52. S. R. Virani, J. R. Saini, and S. Sharma, "Adoption of massive open online courses (MOOCs) for blended learning: the Indian educators' perspective," Interact. Learn. Environ., vol. 0, no. 0, pp. 1-17, 2020 doi: 10.1080/10494820.2020.1817760.

53. A. Verma, S. Verma, P. Garg, and R. Godara, "Online Teaching During COVID-19: Perception of Medical Undergraduate Students," Indian Journal of Surgery, vol. 82, no. 3. pp. 299-300, 2020, doi: 10.1007/s12262-020-02487-2.

54. J. Quay et al., "What future/s for outdoor and environmental education in a world that has contended with COVID-19?," $J$ Outdoor Environ. Educ., 2020, doi: 10.1007/s42322-020-00059-2.

55. H. Lopes and V. McKay, "Adult learning and education as a tool to contain pandemics: The COVID-19 experience," Int. Rev. Educ., vol. 66, no. 4, pp. 575-602, Aug. 2020, doi: 10.1007/s11159-020-09843-0.

56. L.-A. Perryman and B. De los Arcos, "Women's empowerment through openness: OER, OEP and the Sustainable Development Goals," Open Prax., vol. 8, no. 2, May 2016, doi: 10.5944/openpraxis.8.2.289.

57. S. P. Karunanayaka, S. Naidu, J. C. N. Rajendra, and H. U. W. Ratnayake, "From OER to OEP: Shifting Practitioner Perspectives and Practices with Innovative Learning Experience Design," Open Prax., vol. 7, no. 4, Nov. 2015, doi: 10.5944/openpraxis.7.4.252.

58. E. Ossiannilsson and A. Creelman, "OER, Resources for learning Experiences from an OER Project in Sweden [Elektronisk resurs],' Eur. J. Open, Distance E-learning, vol. 15, no. 1, pp. 195-220, 2012.

59. E. Ossiannilsson, "OER and OEP for Access, Equity, Equality, Quality, Inclusiveness, and Empowering Lifelong Learning," Int. J. Open Educ. Resour., vol. 1, no. 2, pp. 1-22, 2019, doi: 10.18278/ijoer.1.2.9.

60. X. Zhu and J. Liu, "Education in and After Covid-19: Immediate Responses and Long-Term Visions," Postdigital Sci. Educ., vol. 2, no. 3, pp. 695-699, Oct. 2020, doi: 10.1007/s42438-020-00126-3.

61. R. Huang, A. Tlili, T. W. Chang, X. Zhang, F. Nascimbeni, and D. Burgos, "Disrupted classes, undisrupted learning during COVID-19 outbreak in China: application of open educational practices and resources," Smart Learn. Environ., vol. 7, no. 1, Dec. 2020, doi: 10.1186/s40561-020-00125-8.

62. D. M. Osina, G. P. Tolstopyatenko, and A. A. Malinovsky, "Digitalization of higher legal education in russia in the age of covid-19," in Lecture Notes in Networks and Systems, vol. 139, Springer, 2021, pp. 392-398.

63. Q. Zhang et al., "The evaluation of online course of Traditional Chinese Medicine for MBBS international students during the COVID-19 epidemic period," Integr. Med. Res., vol. 9, no. 3, Sep. 2020, doi: 10.1016/j.imr.2020.100449.

64. A. E. Al Lily, A. F. Ismail, F. M. Abunasser, and R. H. Alhajhoj Alqahtani, "Distance education as a response to pandemics: Coronavirus and Arab culture," Technol. Soc., vol. 63, Nov. 2020 doi: 10.1016/j.techsoc.2020.101317.

65. N Mahalakshmi, M Mahendraprabu, Mani Mookkiah, Sathish Kumar, "Work Values of Secondary Grade Teachers based on certain selected variables," Journal of Xi'an University of Architecture \& Technology.,12(3), 4910-4918 (2020).

\section{AUTHORS PROFILE}

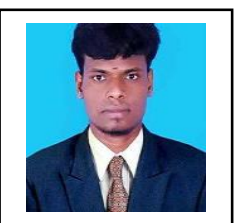

K.Sathish Kumar, Research Scholar, Departmen of Education, Alagappa University, Karaikudi, India.

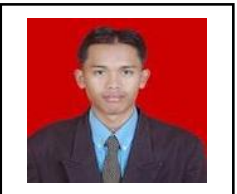

Irwan Fathurrochman, Lecturer, Department of Educational Management, Institute Agama Islam Negeri Curup, Indonesia.

Published By:

Blue Eyes Intelligence Engineering

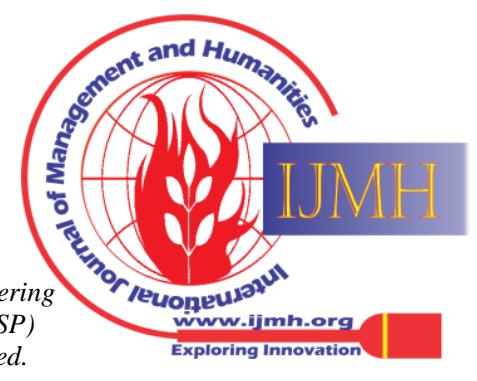




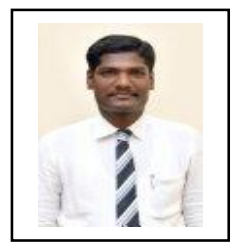

M.Mahendra Prabu, Assistant Professor,

Department of Education, Alagappa University, Karaikudi, India.

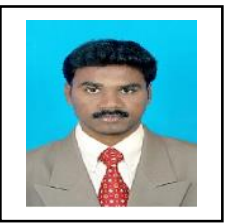

R.Ramnath, Department of Education, Assistant Professor, Alagappa University, Karaikudi, India.

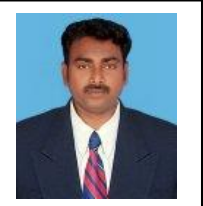

N.Sasi Kumar, Assistant Professor, Department of Education, Alagappa University, Karaikudi, India.

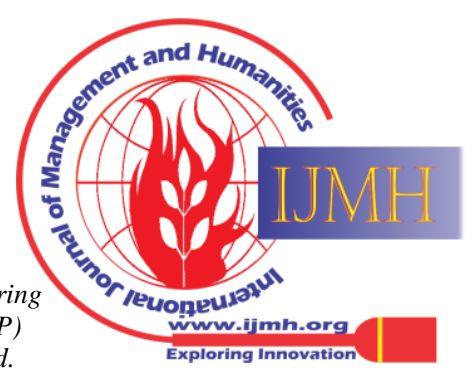

